\title{
Interaction of prenatal maternal smoking, interleukin 13 genetic variants and DNA methylation influencing airflow and airway reactivity
}

\author{
Veeresh K Patil ${ }^{1,2^{*}}$, John W Holloway ${ }^{2,3}$, Hongmei Zhang ${ }^{4}$, Nelis Soto-Ramirez ${ }^{4}$, Susan Ewart ${ }^{5}$, S Hasan Arshad ${ }^{1,2}$ \\ and Wilfried Karmaus ${ }^{4}$
}

\begin{abstract}
Background: Asthma is characterized by airflow limitation and airway reactivity (AR). Interleukin-13 (IL-13) is involved in the pathogenesis of asthma. Two functional SNPS, rs20541 and rs1800925, of the IL-13 gene (IL13) have been frequently associated with asthma-related lung functions. However, genetic variation alone does not fully explain asthma risk. DNA-methylation (DNA-M) is an epigenetic mechanism that regulates gene expression and can be influenced by both environment and genetic variants. To explore the interplay of prenatal maternal smoking, genetic variants and DNA-M, we used a two-stage model: (1) identifying cytosine phosphate guanine (CpG) sites where DNA-M is influenced by the interaction between genetic variants and maternal smoking during pregnancy (conditional methQTL (methylation quantitative trait loci)); and (2) determining the effect of the interaction between DNA-M of CpG (from stage 1) and SNPs (modifying genetic variants; modGV) on airflow limitation and AR in 245 female participants of the Isle of Wight birth cohort. DNA-M was assessed using the Illumina Infinium HumanMethylation450 BeadChip.
\end{abstract}

Findings: Six CpG sites were analyzed in stage 1. DNA-M at cg13566430 was influenced by interaction of maternal smoking during pregnancy and rs20541. In stage 2, genotype at rs1800925 interacted with DNA-M at cg13566430 significantly affecting airflow limitation $(P=0.042)$ and $A R(P=0.01)$.

Conclusion: Both genetic variants and environment affect DNA-M. This study supports the proposed two-stage model (methQTL and modGV) to study genetic variants, environment and DNA-M interactions in asthma-related lung function.

Keywords: Asthma genetics and epigenetics, Airway reactivity, DNA methylation, IL13 gene, Lung functions, Maternal smoking during pregnancy

\section{Findings}

Asthma is a chronic airway disease characterized by airflow limitation and airway reactivity (AR) and exhibits wide heterogeneity in disease susceptibly and phenotypes. Multiple genes, gene-gene and gene-environment interactions have been shown to play a role in determining susceptibility to

\footnotetext{
* Correspondence: vkp1n10@soton.ac.uk

'David Hide Asthma and Allergy Research Centre, St Mary's Hospital,

Newport, Isle of Wight PO30 5TG, UK

${ }^{2}$ Clinical and Experimental Sciences, Faculty of Medicine, University of

Southampton, Southampton, UK

Full list of author information is available at the end of the article
}

asthma and associated phenotypes of lung function and AR. Maternal smoking during pregnancy is a significant risk factor for developing asthma in offspring [1] and can affect offspring lung function [2]. Interleukin-13 (IL-13) is a recognized effector in airway inflammation, reactivity and remodeling. IL13 is located on chromosome 5q31, and has been consistently associated with asthma [3,4]. Several functional genetic variants occur in IL13 including rs1800925 $(-1112 \mathrm{C} / \mathrm{T})$ and $\mathrm{rs} 20541(\mathrm{R} 130 \mathrm{Q},+2044 \mathrm{~A} / \mathrm{G})$. Recent meta-analyses have shown that both SNPs are associated with asthma risk [5,6] and with forced expiratory

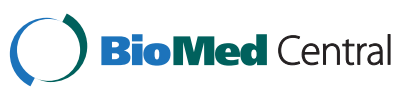


volume in 1 second $\left(\mathrm{FEV}_{1}\right)$ and $\mathrm{FEV}_{1} /$ forced vital capacity (FVC) in asthmatics $[7,8]$. In severe asthma, monoclonal antibody to IL-13 use is associated with improvement in lung function in humans [9] and airway hyper-responsiveness in a murine model [10].

DNA-methylation (DNA-M) represents a site of molecular interaction between the environment and genome. There is growing evidence that DNA-M plays a role in complex diseases like asthma [11] and can be modified by environmental exposures such as tobacco smoke [12] as well as by disease-associated genotypes [13]. We have previously shown that IL13 polymorphism modifies the impact of in utero tobacco smoke exposure on childhood asthma, suggesting a role for gene-environment interaction [14]. Recently we have also shown that genetic variants in the IL-4 receptor interact with DNA-M to determine risk of asthma [15]. DNA-M is a potential integrator of different signals affecting disease susceptibility, with both environment and genotype influencing methylation levels. Karmaus and colleagues [16] proposed a two-stage model to incorporate the role of genetic variants, environment and DNA-M interactions in asthma. In stage 1, an environmental exposure and genetic variant interact to influence DNA-M at a specific site in an adjacent locus. This stage identifies the conditional methQTL (methylation quantitative trait loci) and the change in DNA-M once established can differentially regulate gene activity. In stage 2 , the phenotypic effects of sequence variants of the gene (modifiable genetic variants (modGVs)) can be modified by the pre-established methylation by the conditional methQTL. This two stage model for asthma-related lung function is depicted in Figure 1. Given our previous observation of the interaction between maternal smoke exposure and genotype in determining asthma, we hypothesize that this interaction

\section{Two stage model}

Linear regression model

(Screening for conditional methQTLs)

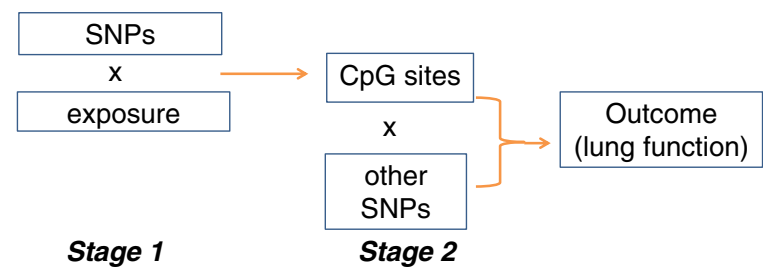

Figure 1 Two-stage model to investigate environment, SNP and DNA methylation interactions influencing asthma-related lung functions (Modified from Karmaus et al. [16]. CpG, cytosine phosphate guanine; methQTL, methylation, quantitative trait loci (genetic variants that change the susceptibility for DNA methylation); modGV, modifiable genetic variants (genetic variants that are modified by DNA methylation). would occur through a mechanism involving methQTL and/or modGVs.

\section{Study population and assessments}

The Isle of Wight birth cohort $(n=1,456)$ was established in 1989 and has been followed up through childhood. At 18 years of age, spirometry and bronchial challenge tests were done according to American Thoracic Society guidelines $[17,18]$. We analyzed lung function measurements and DNA-M data of 245 females aged 18 years who were randomly selected from the cohort population for epigenetic studies. Comparison of the analyzed sample with whole cohort females in terms of risk factors have been described elsewhere [15]. A continuous measure of AR (dose response slope (DRS)) was used. DRS is the gradient of $\mathrm{FEV}_{1}$ drop from baseline with each successive incremental dose of methacholine administered. A transformation of $\log _{10}(\mathrm{DRS}+10)$ was required to satisfy the distributional assumption of normal data. A higher positive value of this transformation signifies greater AR. A description of the 18-year follow-up of the cohort is previously reported [19].

\section{Genotyping and SNP selection}

DNA was isolated from peripheral blood leucocytes collected at age 18. IL13 polymorphisms were genotyped as described by Sadeghnejad and colleagues [14]. Two known functional SNPs, rs1800925 $(\mathrm{n}=234)$ and $\mathrm{rs} 20541$ $(n=235)$, frequently associated with asthma and related lung functions were used in this analysis. These SNPs were not in linkage disequilibrium in this cohort as described elsewhere [14].

\section{DNA-methylation}

One microgram of DNA was bisulfite-treated using the EZ 96-DNA-methylation kit (Zymo Research, Irvine, CA, USA), following the manufacturer's protocol. Genomewide DNA- $M$ was assessed using the Illumina InfiniumHumanMethylation450 BeadChip (Illumina, Inc., Hayward, CA, USA) as described previously [15].

\section{Statistical methods}

The pre-processed DNA-M beta $(\beta)$ values, presented as the proportion of intensity of methylated $(\mathrm{M})$ over the sum of methylated $(\mathrm{M})$ and unmethylated $(\mathrm{U})$ sites $(\beta=\mathrm{M} /$ $[\mathrm{c}+\mathrm{M}+\mathrm{U}]$ with $\mathrm{c}$ being a constant to prevent dividing by zero), were used to estimate the effect of DNA-M [20]. The R-package IMA in Bioconductor (IMA is implemented in the $\mathrm{R}$ language and is freely available from http://www. rforge.net/IMA) was used for the pre-processing [21]. SNP genotype-dependent methylation was analyzed using the Kruskal-Wallis test. Interaction was tested using multiple linear regressions. Statistical analyses were performed using IBM SPSS Statistics, Version-19.0 (IBM SPSS Statistics for 
Table 1 Location, position and description of rs 1800925 , rs20541 and CpG sites on the promoter region of IL13 gene

\begin{tabular}{|c|c|c|c|c|c|}
\hline SNP & $\begin{array}{l}\text { Chromosomal } \\
\text { location }\end{array}$ & Position & Genotypes & n $(9$ & \\
\hline \multirow[t]{3}{*}{ rs1800925 } & \multirow[t]{3}{*}{ 5:131992809 } & \multirow{3}{*}{$\begin{array}{l}5^{\prime} \text { Promoter } \\
\text { upstream }\end{array}$} & $\pi$ & \multicolumn{2}{|c|}{$8(3.4 \%)$} \\
\hline & & & $\mathrm{CT}$ & \multicolumn{2}{|c|}{68 (28.8\%) } \\
\hline & & & $\mathrm{CC}$ & \multicolumn{2}{|c|}{158 (67.8\%) } \\
\hline \multirow[t]{3}{*}{ rs20541 } & 5:131995964 & Exon 4 & $\mathrm{AA}$ & \multicolumn{2}{|c|}{$10(4.3 \%)$} \\
\hline & & & $A G$ & \multicolumn{2}{|c|}{$66(28.1 \%)$} \\
\hline & & & GG & \multicolumn{2}{|c|}{159 (67.7\%) } \\
\hline CpG & & & Median & \multicolumn{2}{|c|}{$\begin{array}{c}\text { Percentiles } \\
(5 \%, 95 \%)\end{array}$} \\
\hline cg13566430 & 5:131992455 & TSS1500 & 0.18 & 0.14 & 0.23 \\
\hline cg04303330 & 5: 131992430 & TSS1500 & 0.30 & 0.23 & 0.36 \\
\hline cg06584121 & 5: 131993818 & TSS200 & 0.80 & 0.730 & 0.84 \\
\hline cg06967316 & 5: 131993853 & TSS200 & 0.74 & 0.66 & 0.80 \\
\hline cg14523284 & 5: 131993614 & TSS1500 & 0.86 & 0.83 & 0.89 \\
\hline cg15329179 & 5: 131993728 & TSS200 & 0.87 & 0.81 & 0.90 \\
\hline
\end{tabular}

CpG, cytosine phosphate guanine; TSS200, 200 base pairs from transcription start site; TSS1500, 1500 base pairs from transcription start site.

Windows, Version 19.0. Armonk, NY, USA: IBM Corp,). The statistical significance was set at 0.05 .

\section{Results}

Six cytosine phosphate guanine $(\mathrm{CpG})$ sites were identified in the promoter region of IL13. The location and description of the CPG sites and of SNPs are shown in
Table 1. All the six CpG sites spanning the promoter region of IL13 were analyzed in Stage 1 . The effect of maternal smoking during pregnancy interacting with both SNPs was explored independently for DNA-M at each CpG site. DNA-M at cg13566430 was influenced by the interaction of rs20541 and maternal smoking during pregnancy $(P=0.043)$; this remained significant after correcting for personal smoking at 18 years $(P=0.041)$. DNA-M at cg13566430 also showed a genotype dependent methylation for rs1800925 (Kruskall Wallis test $P<0.001$; Figure 2).

In the next step, the interaction between DNA-M at cg13566430 and rs1800925 genotype on lung function $\left(\mathrm{FEV}_{1} / \mathrm{FVC}\right.$ and DRS) was explored. DNA-M at cg13566430 significantly interacted with rs1800925 genotype to determine $\mathrm{FEV}_{1} / \mathrm{FVC}$ and DRS (Table 2). In subjects with the $\mathrm{TT}$ genotype, $\mathrm{FEV}_{1} / \mathrm{FVC}$ increases with increasing methylation of cg13566430 (coefficient 3.274, $P=0.042$ ), for the CT genotype group the increase was smaller (coefficient $0.799, P=0.086$ ) and $C C$ was the reference genotype. The graph in Figure 3 provides a visual description of the effect of DNA-M at cg13566430 and rs1800925 on $\mathrm{FEV}_{1} / \mathrm{FVC}$. DRS decreases quickly with increasing methylation of cg13566430 in TT genotype (coefficient $-27.497, P=0.010$ ), while the drop in DRS in CT is insignificant (coefficient $-0.809, P=0.742$ ).

\section{Discussion}

This study tested a two-stage model for integrating the interactions of maternal smoking during pregnancy,

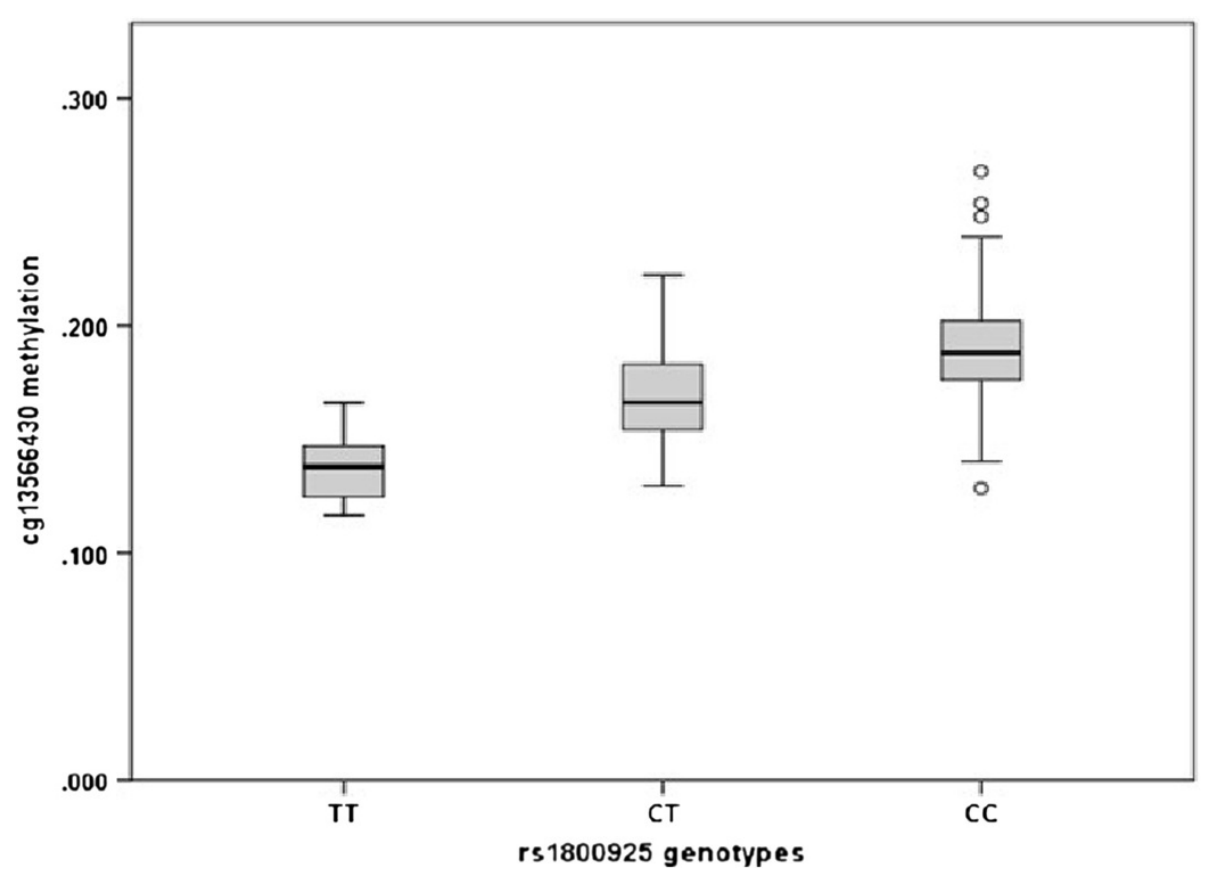

Figure 2 Whisker plot showing IL13 rs1800925 genotype-dependant DNA methylation of cg13566430. 


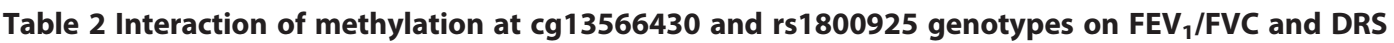

\begin{tabular}{|c|c|c|c|c|c|c|c|}
\hline & & \multicolumn{3}{|c|}{$\mathrm{FEV}_{1} / \mathrm{FVC}$} & \multicolumn{3}{|c|}{ DRS } \\
\hline & & Estimate & $95 \% \mathrm{Cl}$ & $P$ & Estimate & $95 \% \mathrm{Cl}$ & $P$ \\
\hline \multicolumn{8}{|l|}{ Main effects } \\
\hline cg13566430 & & 0.175 & -0.166 to 0.517 & 0.313 & -0.568 & -2.361 to 1.226 & 0.533 \\
\hline \multirow[t]{3}{*}{ rs20541 } & AA & 0.020 & -0.024 to 0.064 & 0.369 & -0.075 & -0.278 to 0.129 & 0.469 \\
\hline & AG & 0.006 & -0.014 to 0.026 & 0.548 & 0.036 & -0.076 to 0.149 & 0.523 \\
\hline & GG & & Reference & & & Reference & \\
\hline \multirow[t]{3}{*}{ rs1800925 } & $\mathrm{TT}$ & 0.030 & -0.019 to 0.079 & 0.231 & 0.299 & 0.045 to 0.554 & 0.021 \\
\hline & $\mathrm{CT}$ & -0.001 & -0.021 to 0.019 & -0.001 & -0.026 & -0.134 to 0.083 & 0.644 \\
\hline & $\mathrm{CC}$ & & Reference & & & Reference & \\
\hline \multicolumn{8}{|l|}{ Interaction } \\
\hline \multirow[t]{3}{*}{ rs1800925 } & $\mathrm{TT}$ & -0.412 & -0.855 to 0.030 & 0.068 & 3.989 & 1.194 to 6.785 & 0.005 \\
\hline & CT & -0.134 & -0.296 to 0.028 & 0.106 & 0.124 & -0.733 to 0.982 & 0.775 \\
\hline & $\mathrm{CC}$ & & Reference & & & Reference & \\
\hline cg13566430 & & 0.174 & -0.301 to 0.648 & 0.472 & 0.624 & -1.926 to 3.174 & 0.629 \\
\hline \multirow[t]{3}{*}{ rs $1800925 \times$ cg13566430 } & $\mathrm{TT}$ & 3.274 & 0.114 to 6.434 & 0.042 & -27.497 & -48.283 to -6.710 & 0.010 \\
\hline & $\mathrm{CT}$ & 0.799 & -0.114 to 1.712 & 0.086 & -0.809 & -5.661 to 4.043 & 0.742 \\
\hline & $\mathrm{CC}$ & & Reference & & & Reference & \\
\hline
\end{tabular}

DRS, dose response slope; $\mathrm{FEV}_{1}$, forced expiratory volume in 1 second; FVC, forced vital capacity.

genetic variants and DNA-M for an asthma candidate gene $I L 13$. We show that interaction of a functional $I L 13$ SNP, rs20541, and maternal smoking during pregnancy influenced DNA-M at cg13566430. We also show that DNA-M at cg13566430 interacts with genotype of another functional SNP, rs1800925, to affect airflow limitation and AR. Michel and colleagues [22] examined the effect of farm exposure on DNA-M of ten asthma candidate genes and found that DNA-M at one IL13 site (spanning rs1800925; similar to the site in our study) was more methylated in the exposed group compared to the non-exposed group. They did not see significant

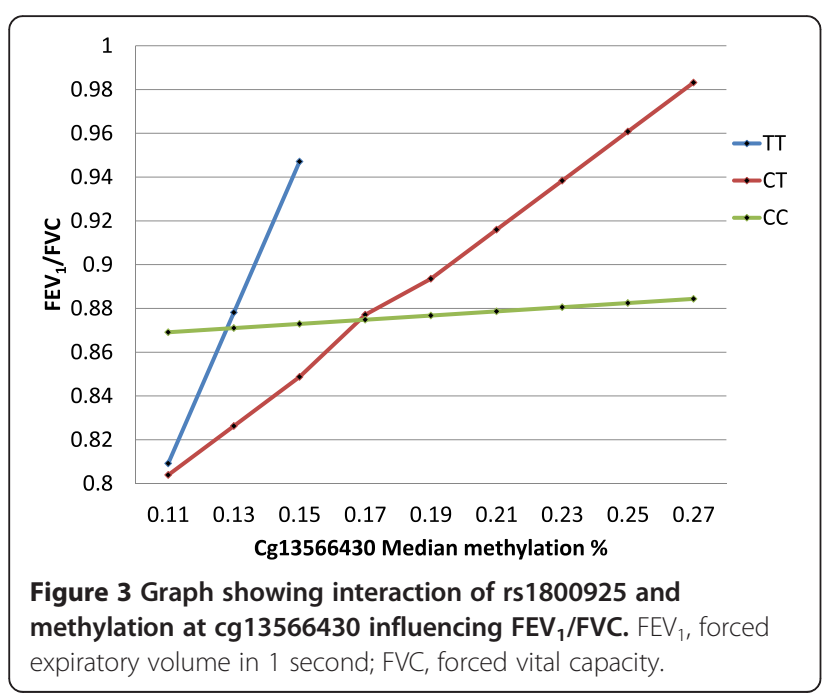

differential methylation of IL13 between asthmatic and non-asthmatic children but asthma-related traits were not tested and also the interaction with genetic variants was not examined. Our approach identifies the effect of environmental exposure and genetic variants on DNA$\mathrm{M}$ and then also combines the interaction of other modifiable genetic variants with DNA-M on the outcomes. We show genotype-dependent DNA-M in the IL13 promoter region; methylation at cg13566430 revealed variation in levels dependent on the genotype of rs1800925, as seen in other genes [23]. This varying distribution of DNA-M across genotypes supports the plausible role for DNA-M in the pathway between genotype and phenotype.

There are some limitations to this study. While DNA-M measurement using Illumina Infinium-HumanMethylation 450 arrays has been shown to have reproducibility and high validity [24], technical replication of the DNA-M measurements has not been undertaken. We have not measured DNA-M in airway tissue; however, the major source of IL-13 production in the airways is inflammatory cells, and methylation measurements in peripheral blood are likely to better reflect asthma-related immune mechanisms. Cell composition in the peripheral blood can influence DNA-M; however, cell composition alone cannot explain the differential methylation observed [22]. Focusing only on female participants is a limitation; however, the results should be encouraging for further studies to replicate the model. The interaction effects seen may not imply a direct relationship between genotype and 
altered methylation. Genotype may also alter other epigenetic processes such as chromatin remodeling and this may then lead to altered DNA-M.

The effect of environment, genotype and DNA-M was seen for two different, but equally important and objective, characteristics of asthma: airflow limitation and AR. Similar to Michel and colleagues [22] we did not see an effect on asthma as an outcome (results not shown); however, the observed effect on asthma-related objective measures avoids plausible bias of reported asthma. Methylation of the promoter region can regulate gene transcription [25] and we have shown that promoter region methylation is dependent on genotype, and the interplay of the environment, genotype and DNA-M influence the phenotype.

While requiring replication in an independent cohort, the results show the interplay of prenatal maternal smoking, genetic variants and DNA-M of IL13 influencing asthma-related lung function. This highlights the need to consider environment, genotype and DNA-M together when seeking to understand the pathogenesis of complex disease, as DNA-M plays a role of integrator of multiple disease pathway signals.

\begin{abstract}
Abbreviations
AR: Airway reactivity; CpG: Cytosine phosphate guanine; DNA-M: DNA methylation; DRS: Dose response slope; $\mathrm{FEV}_{1}$ : Forced expiratory volume in 1 second; FVC: Forced vital capacity; IL: Interleukin; methQTL: Methylation, quantitative trait loci; modGV: Modifiable genetic variant; SNP: Single nucleotide polymorphism.
\end{abstract}

\section{Competing interests}

The authors declare that they have no competing interests.

\section{Authors' contributions}

VKP contributed to design, analysis and wrote the manuscript draft. JWH contributed to design, interpretation of the data, manuscript preparation and review for intellectual content. $\mathrm{HZ}$ contributed to analysis, interpretation of the data and manuscript preparation. NSR contributed to data analysis and manuscript preparation. SE contributed to design, acquisition of data and revising the manuscript. SHA contributed to the concept, acquisition of data and review for intellectual content. WK contributed to the concept, design, analysis and review for intellectual content. All the authors have access to the data and have approved the manuscript version submitted.

\section{Acknowledgements}

We would like to thank all the participants of the Isle of Wight birth cohort, Dr A Raza and the research team at David Hide Asthma \& Allergy Research Centre, Isle of Wight, for collecting the data and Nikki Graham for technical support. We thank the High-Throughput Genomics Group at the Wellcome Trust Centre for Human Genetics (funded by Wellcome Trust grant reference 090532/Z/09/Z and MRC Hub grant G0900747 91070) for the generation of the methylation data.

\section{Funding sources}

The epigenetic investigation was supported by National Institutes of Health, USA (R01-Al091905, R01-Al061471, and R21-Al099367). The 18-year assessment of the 1989 Isle of Wight birth cohort was funded by grants from the National Institutes of Health, USA (R01-HL082925) and National Eczema Society/British Dermatological Nursing Group Research Awards.

\section{Author details}

'David Hide Asthma and Allergy Research Centre, St Mary's Hospital, Newport, Isle of Wight PO30 5TG, UK. ${ }^{2}$ Clinical and Experimental Sciences, Faculty of Medicine, University of Southampton, Southampton, UK. ${ }^{3}$ Human Development and Health, Faculty of Medicine, University of Southampton, Southampton, UK. ${ }^{4}$ Division of Epidemiology, Biostatistics, \& Environmental Health, School of Public Health, University of Memphis, Memphis, TN, USA. ${ }^{5}$ Department of Large Animal Clinical Sciences, Michigan State University, East Lansing, MI, USA.

Received: 25 June 2013 Accepted: 1 November 2013

Published: 6 December 2013

\section{References}

1. Karmaus W, Dobai AL, Ogbuanu I, Arshard SH, Matthews S, Ewart S: Long-term effects of breastfeeding, maternal smoking during pregnancy, and recurrent lower respiratory tract infections on asthma in children. J Asthma 2008, 45:688-695.

2. Wang $L$, Pinkerton KE: Detrimental effects of tobacco smoke exposure during development on postnatal lung function and asthma. Birth Defects Res C Embryo Today 2008, 84:54-60.

3. Li X, Howard TD, Zheng SL, Haselkorn T, Peters SP, Meyers DA, Bleecker ER: Genome-wide association study of asthma identifies RAD50-IL13 and HLA-DR/DQ regions. J Allergy Clin Immunol 2010, 125:328-3354.

4. Holloway JW, Yang IA, Holgate ST: Genetics of allergic disease. J Allergy Clin Immunol 2010, 125(2 Suppl 2):S81-S94.

5. Nie W, Liu Y, Bian J, Li B, Xiu Q: Effects of polymorphisms $-1112 \mathrm{C} / \mathrm{T}$ and $+2044 \mathrm{~A} / \mathrm{G}$ in interleukin-13 gene on asthma risk: a meta-analysis. PLOS One 2013, 8:e56065.

6. Cui L, Jia J, Ma CF, Li SY, Wang YP, Guo XM, Li Q, Yu HB, Liu WH, Gao LB: IL-13 polymorphisms contribute to the risk of asthma: a meta-analysis. Clin Biochem 2012, 45:285-288.

7. Beghe B, Hall IP, Parker SG, Moffatt MF, Wardlaw A, Connolly MJ, Fabbri LM, Ruse C, Sayers I: Polymorphisms in IL13 pathway genes in asthma and chronic obstructive pulmonary disease. Allergy 2010, 65:474-481.

8. Park H-W, Lee J-E, Kim S-H, Kim Y-K, Min K-U, Kim Y-Y, Cho S-H: Genetic variation of IL13 as a risk factor of reduced lung function in children and adolescents: a cross-sectional population-based study in Korea. Respir Med 2009, 103:284-288.

9. Corren J, Lemanske RF, Hanania NA, Korenblat PE, Parsey MV, Arron JR, Harris JM, Scheerens H, Wu LC, Su Z, Mosesova S, Eisner MD, Bohen SP, Matthews JG: Lebrikizumab treatment in adults with asthma. N Engl J Med 2011, 365:1088-1098.

10. Yang G, Volk A, Petley T, Emmell E, Giles-Komar J, Shang X, Li J, Das AM, Shealy D, Griswold DE, Li L: Anti-IL-13 monoclonal antibody inhibits airway hyperresponsiveness, inflammation and airway remodeling. Cytokine 2004, 28:224-232.

11. Kabesch M, Michel S, Tost J: Epigenetic mechanisms and the relationship to childhood asthma. Eur Respir J 2010, 36:950-961.

12. Joubert BR, Haberg SE, Nilsen RM, Wang X, Vollset SE, Murphy SK, Huang Z, Hoyo C, Midttun O, Cupul-Uicab LA, Ueland PM, Wu MC, Nystad W, Bell DA, Peddada SD, London SJ: $450 \mathrm{~K}$ Epigenome-wide scan identifies differential DNA methylation in newborns related to maternal smoking during pregnancy. Environ Health Perspect 2012, 120:1425-1431.

13. Bell CG, Finer S, Lindgren CM, Wilson GA, Rakyan VK, Teschendorff AE, Akan P, Stupka E, Down TA, Prokopenko I, Morison IM, Mill J, Pidsley R, International Type 2 Diabetes 1q C, Deloukas P, Frayling TM, Hattersley AT, McCarthy MI, Beck S, Hitman GA: Integrated genetic and epigenetic analysis identifies haplotype-specific methylation in the FTO type 2 diabetes and obesity susceptibility locus. PLoS One 2010, 5:e14040.

14. Sadeghnejad A, Karmaus W, Arshad SH, Kurukulaaratchy R, Huebner M Ewart S: IL13 gene polymorphisms modify the effect of exposure to tobacco smoke on persistent wheeze and asthma in childhood, a longitudinal study. Respir Res 2008, 9:2.

15. Soto-Ramirez N, Arshad SH, Holloway JW, Zhang H, Schauberger E, Ewart S, Patil $V$, Karmaus W: The interaction of genetic variants and DNA methylation of the interleukin-4 receptor gene increase the risk of asthma at age 18 years. Clin Epigenetics 2013, 5:1.

16. Karmaus W, Ziyab AH, Everson T, Holloway JW: Epigenetic mechanisms and models in the origins of asthma. Curr Opin Allergy Clin Immunol 2013, 13:63-69. 
17. Crapo RO, Casaburi R, Coates AL, Enright PL, Hankinson JL, Irvin CG, MacIntyre NR, McKay RT, Wanger JS, Anderson SD, Cockcroft DW, Fish JE, Sterk PJ: Guidelines for methacholine and exercise challenge testing1999. This official statement of the American Thoracic Society was adopted by the ATS board of directors, July 1999. Am J Respir Crit Care Med 2000, 161:309-329.

18. Miller MR, Hankinson J, Brusasco V, Burgos F, Casaburi R, Coates A, Crapo R, Enright $P$, van der Grinten $C P$, Gustafsson $P$, Jensen $R$, Johnson DC, MacIntyre N, McKay R, Navajas D, Pedersen OF, Pellegrino R, Viegi G, Wanger J: Standardisation of spirometry. Eur Respir J 2005, 26:319-338.

19. Raza A, Kurukulaaratchy RJ, Grundy JD, Clayton CB, Mitchell FA, Roberts G, Ewart S, Sadeghnejad A, Arshad SH: What does adolescent undiagnosed wheeze represent? Findings from the Isle of Wight cohort. Eur Respir J 2012, 40:580-588.

20. Kuan PF, Wang S, Zhou X, Chu H: A statistical framework for Illumina DNA methylation arrays. Bioinformatics 2010, 26:2849-2855.

21. Wang D, Yan L, Hu Q, Sucheston LE, Higgins MJ, Ambrosone CB, Johnson CS, Smiraglia DJ, Liu S: IMA: an R package for high-throughput analysis of Illumina's 450K Infinium methylation data. Bioinformatics 2012, 28:729-730.

22. Michel S, Busato F, Genuneit J, Pekkanen J, Dalphin JC, Riedler J, Mazaleyrat $\mathrm{N}$, Weber J, Karvonen AM, Hirvonen MR, Braun-Fahrlander C, Lauener R, von Mutius E, Kabesch M, Tost J, group Ps: Farm exposure and time trends in early childhood may influence DNA methylation in genes related to asthma and allergy. Allergy 2013, 68:355-364.

23. Bell JT, Tsai PC, Yang TP, Pidsley R, Nisbet J, Glass D, Mangino M, Zhai G, Zhang F, Valdes A, Shin SY, Dempster EL, Murray RM, Grundberg E, Hedman AK, Nica A, Small KS, Mu TC, Dermitzakis ET, McCarthy MI, Mill J, Spector TD, Deloukas P: Epigenome-wide scans identify differentially methylated regions for age and age-related phenotypes in a healthy ageing population. PLoS Genet 2012, 8:e1002629.

24. Bibikova M, Barnes B, Tsan C, Ho V, Klotzle B, Le JM, Delano D, Zhang L, Schroth GP, Gunderson KL, Fan J-B, Shen R: High density DNA methylation array with single CpG site resolution. Genomics 2011, 98:288-295.

25. Razin $\mathrm{A}: \mathrm{CpG}$ methylation, chromatin structure and gene silencing-a three-way connection. EMBO J 1998, 17:4905-4908.

doi:10.1186/1868-7083-5-22

Cite this article as: Patil et al:: Interaction of prenatal maternal smoking, interleukin 13 genetic variants and DNA methylation influencing airflow and airway reactivity. Clinical Epigenetics 2013 5:22.

\section{Submit your next manuscript to BioMed Central and take full advantage of:}

- Convenient online submission

- Thorough peer review

- No space constraints or color figure charges

- Immediate publication on acceptance

- Inclusion in PubMed, CAS, Scopus and Google Scholar

- Research which is freely available for redistribution 